\title{
集学的治療を要した中毒性表皮壊死症/薬剤過敏症症候群 オーバーラップ病態の一救命例
}

\author{
田中 暢 西木 正照 小玉 正智 \\ 社会医療法人信愛会畷生会脳神経外科病院内科・救急集中治療部 \\ （率574-8511 大阪府四條畷市中野本町 28-1） \\ †著者連絡先：医療法人医誠会医誠会病院麻醉科 ( ( 533-0022 大阪府大阪市東淀川区菅原 6-2-25)
}

Key words: (1) drug induced hypersensitivity syndrome, (2) human herpes virus 6, (3) toxic epidermal necrolysis

\section{はじめに}

中毒性表皮壊死症（toxic epidermal necrolysis， TEN) と薬剤過敏症症候群 (drug induced hypersensitivity syndrome, DIHS) はともに致死的重症薬疹 であり 1) 3), 稀に合併することがあるとされる11,4)。 ともに重篤な全身症状を呈することがあり，治療に当 たっては慎重な全身管理を要する。我々はTENとし て治療を開始した症例で, 遷延する多彩な臓器障害と ヒトヘルペスウィルス6型 (human herpes virus 6, HHV-6) の再活性化を認め, DIHS と診断した症例を経 験した。

\section{症 例}

患者は69歳, 男性。 $161 \mathrm{~cm}, 55 \mathrm{~kg}$ 。感冒症状にて 近医受診し, ホスホマイシン点滴静注および総合感冒 薬, アジスロマイシン, メキタジン, 麻黄の内服を行っ ていた。一旦感冒症状は改善したが, 10 日後より鼻閉 感, 全身倦意感, 食欲不振, 体幹に赤色丘疹が散在性 に出現。血液生化学検査にて肝機能異常 (total bilirubin $0.4 \mathrm{mg} / \mathrm{d} l$, AST $122 \mathrm{IU} / l$, ALT $248 \mathrm{IU} / l$, $\gamma$-glutamyl transpeptidase $241 \mathrm{IU} / l$, alkaline phosphatase $958 \mathrm{IU} / l$, LDH $332 \mathrm{IU} / l$ ) も指摘され薬 剤性肝障害, 薬疹の疑いで紹介入院となった。入院後 の経過を Fig. 1に示す。各種ウイルス検査はいずれも 陰性であり, 特異的 $\operatorname{IgE}$ (immunoglobulin-E) は数種類
の草木などで陽性を示した。皮疹は一旦消裉傾向で あったが，急性胆豪炎の症状が出現し第4病日に経皮 経肝胆囊ドレナージ (percutaneous transhepatic gallbladder drainage, PTGBD) を施行。同時に施行し た上部消化管内視鏡検査では, 胃噴門部を中心として 潰瘍が散在していた。その後も皮疹の再燃と呼吸困難 感, 倦怠感があり, 腎機能障害も出現したことから第 6 病日にICU入室となった。入室時, 意識状態Japan coma scale I-2-R, 体温 $38.0^{\circ} \mathrm{C}$, 血圧 $165 / 80 \mathrm{mmHg}$, 心拍数 $136 / \mathrm{min}, \mathrm{SpO}_{2} 92 \%\left(100 \% \mathrm{O}_{2} 5 \mathrm{l} / \mathrm{min}\right.$ マス ク)。体幹部の赤色膨隆疹は表皮剥離, 水泡を形成し て体表の約 $25 \%$ に広がり, 全身のリンパ節腫脹がみら れた。また, 眼瞼結膜は浮腫状で結膜炎あり, 口腔内 にアフタが多発し, 陰茥・陰囊には小潰瘍を形成して いた。肝胆道系酵素異常はPTGBD 後軽快傾向であっ たが, 好酸球優位の白血球上昇 $60,200 / \mathrm{mm}^{3}$ (好中球 $29.0 \%$, リンパ球 $3.2 \%$, 好酸球 $59.2 \%$ ）を呈していた。 骨髄検査では白血病などの血液疾患は否定的であっ た。診断基準より TEN型薬疹と診断したが, 重篤な 臓器症状よりDIHSの可能性もあるとして気管挿管, ステロイドパルス療法および, 免疫グロブリンを投与 し, 腎機能障害に対して持続的血液透析濾過 (continuous hemodiafiltration, CHDF)を施行した。 その後, 皮疹は紅斑様となり全身に拡大したが, その 他の全身症状は一旦軽快傾向にあった。しかし，第 12 病日に白血球数および好酸球の上昇を認め, 同日深夜

A case of drug induced hypersensitivity syndrome overlapped with toxic epidermal necrolysis successfully treated with critical care

Toru Tanaka, Masateru Nishiki, Masashi Kodama

Department of Medical Emergency and Intensive Care, Tesseikai Brain Neurosurgery Hospital (28-1 Nakanohonmachi, Shijonawate, Osaka 5748511, Japan)

J Jpn Soc Intensive Care Med 2013;20:659-60. 


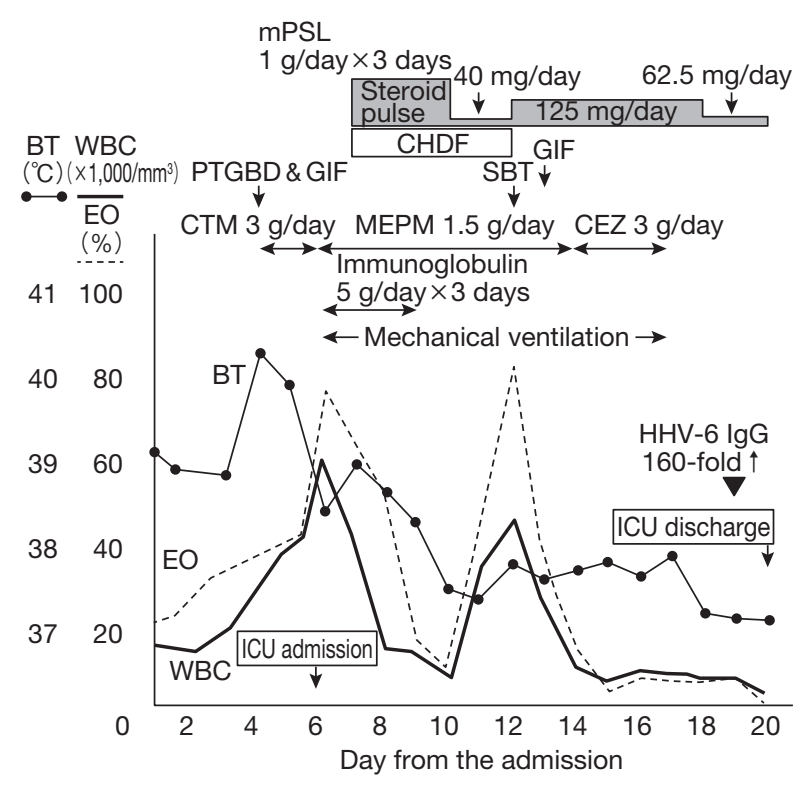

Fig. 1 Clinical course

$\mathrm{BT}$, body temperature; $\mathrm{CEZ}$, cefazolin; $\mathrm{CHDF}$, continuous hemodiafiltration; CTM, cefotiam; EO, eosinophil granulocyte; GIF, gastrointestinalfiberscopy; HHV-6 IgG, human herpes virus-6 immunoglobulinG; MEPM, meropenem; mPSL, methylprednisolone; PTGBD, percutaneous transhepatic gallbladder drainage; SBT, Sengstaken-Blakemore tube.

には大量の上部消化管出血から出血性ショックとなっ た。Sengstaken-Blakemore tubeを挿入しつつ, CHDFを中止し, 大量輸血にて循環状態の安定化を 図った上で，上部消化管内視鏡的止血術を施行した。 DIHSの病態の悪化も考え，ステロイドを増量した。 それ以降は皮疹と全身状態は改善し第 17 病日に人工 呼吸器から離脱した。第20病日にICU退室, その後 も再燃を認めず第 62 病日に軽快退院となった。なお, 血中ヘルペス 6型 IgG抗体価 (HHV-6 IgG) は, 第19病 日には 160 倍と再活性化を認め, 第 41 病日には 10 倍 以下と低下していた。

\section{考 察}

TEN は体表面積の $10 \%$ を超える水泡, 表皮剥離・ びらんなどの顕著な表皮の壊死性障害を認めると定義 され5), 本症例もこの定義を満たしていたが，遷延を 続ける皮膚症状と多彩で重篤な臟器症状から DIHS の 可能性も疑った。DIHSは高熱と臟器障害を伴い, 医 薬品中止後も遷延する薬疹で, 発症後 $2 \sim 3$ 週間後に HHV-6の再活性化を生じるとされ, 遷延化する紅斑, 熱発, 肝機能障害, 血液学的異常, リンパ節腫脹, HHV-6の再活性化などで診断される。薬剂アレルギー とウイルス感染が原因となり, 原因薬物はある程度限 定されているが, 本症例のように原因薬物が特定でき
ないDIHS の報告も散見される ${ }^{6)}$ 。HHV-6の再活性化 をきたすことが特徵的とされ，なんらかのアレルギー により発症した病態がHHV-6の再活性化により修飾 され遷延化するもの考えられている1)。本症例では HHV-6 IgG 抗体価が160倍と高值であり, かつ軽快後 では陰転化していたことから，再活性化であったと判 断した。患者は更なる検查は希望されず原因薬物の同 定には至らなかったが, 疑われる全てのアレルゲンに 対するパッチテストやリンパ球幼弱化試験21,6)を行え ば原因薬荗を同定できた可能性はある。TENとDIHS はそれぞれ別の疾患概念であるとされていたが，近年 そのオーバーラップの存在が頻繁に報告されている ${ }^{4)}$ 。 DIHSの治療はTENの治療と共通するものが多いが, さらにDIHS特有の臟器障害に対しての支持療法を要 する2)。一般的にDIHSの臟器障害は中枢神経系障害, 呼吸器障害, 循環器障害, 肝・胆・膵障害など多彩で ある6)。DIHSで直接に消化器症状をきたすことは稀 であるが, 本症例では胃潰瘍, 上部消化管出血を認め た。これは, 薬荗性もしくはストレス性胃潰瘍に DIHSによるストレスおよびCHDF中の抗凝固療法が 重なり, 出血を助長させたものと推測した。

\section{結 語}

皮膚症状と重症藏器障害の病態にHHV-6再活性化 をきたしたDIHS 病態を経験した。臟器障害を呈する 薬疹などのアレルギー性疾患ではDIHSの存在を念頭 に置き, 集中治療管理を行う必要がある。

本論文の要旨は, 第 39 回日本集中治療学会学術集会 $(2012$ 年, 千葉)にて発表した。

なお, 本稿の全ての著者には規定されたCOIはない。

\section{文 献}

1) Tohyama M, Hashimoto K. New aspects of drug-induced hypersensitivity syndrome. J Dermatol 2011;38:222-8.

2) 伊藤正俊. 本邦皮膚科領域に扔けるdrug-induced hypersensitivity syndrome 108症例の臨床的検討. 臨免疫 - ア レルギー科 2006; $46: 630-9$.

3) 長谷川 豊, 江連雅彦, 佐藤泰史, 他. バンコマイシンに よる中毒性表皮壊死症の1例. 日集中医誌 2012;19:253-4.

4) 小田富美子, 藤山幹子, 徳丸 晶, 他. Stevens-Johnson 症 候群と薬片性過敏症症候群のオーバーラップした例. 皮病 診療 2010;32:895-8.

5) 槇田徹次. 中毒性表皮壞死症の治療法の確立をめざして. 日集中医誌 2012;19:160-2.

6) 厚生労働省. 重篤副作用疾患別対応マニュアル。薬剤性過 敏症症候群, 2007. Available from: http://www.info.pmda. go.jp/juutoku/file/jfm0706001.pdf 